\title{
Effect of Indole Acetic Acid Producing Bacteria and Hormone Applications on Essential Oil Components of Satureja hortensis L
}

\author{
Goltay Mosber ${ }^{1}$, Ramazan Çakmakçı ${ }^{2}$, Meral Kutlu ${ }^{1}$, Halit Karagoz ${ }^{1}$, * \\ ${ }^{1}$ Faculty of Agriculture, Department of Field Crops, Atatürk University, Erzurum, Turkey \\ ${ }^{2}$ Faculty of Agriculture, Department of Field Crops, Çanakkale Onsekiz Mart University, Çanakkale, Turkey
}

Email address:

halit_karagoz_25@hotmail.com (H. Karagoz)

${ }^{*}$ Corresponding author

\section{To cite this article:}

Goltay Mosber, Ramazan Çakmakçi, Meral Kutlu, Halit Karagoz. Effect of Indole Acetic Acid Producing Bacteria and Hormone Applications on Essential Oil Components of Satureja hortensis L. Frontiers in Environmental Microbiology. Vol. 5, No. 1, 2019 , pp. $29-35$. doi: 10.11648/j.fem.20190501.14

Received: February 13, 2019; Accepted: March 14, 2019; Published: April 8, 2019

\begin{abstract}
The impacts of plant growth-promoting bacteria on aromatic plant species are poorly known. This study was conducted in order to evaluate possible impacts of mineral fertilizer, plant growth regulators [PGR, Indole 3-acetic acid + benzylaminopurine IAA+BAP and BAP] and five $\mathrm{N}_{2}$-fixing, P-solubilizing, IAA-producing bacterial strains, as biofertilizer on growth, yield and quality characteristics of the plant, essential oil content and major component of the essential of summer savory. GC-MS was used to analyze the hydro-distilled essential oils. Multi-traits bacterial inoculation and PGR applications stimulated overall plant growth, including drug and fresh herb yield, essential oil ratio and yield, crucial oil components such as carvacrol of savory. The presence of at least thirty one compounds were identified in analysed samples, representing 98.7$100 \%$ of the total oil contents. In terms of general categories, the chemical profile of the oils with carvacrol, p-cymene, $\gamma$ terpinene and $\alpha$-terpinene as the basic components was dominated by monoterpene hydrocarbons.
\end{abstract}

Keywords: Plant Growth-Promoting Rhizobacteria, Plant Growth Regulators, Summer Savory,

Essential Oil Component and Yield

\section{Introduction}

The plant hormones are important for the production of essential oil-bearing crops. The concentration, application time and type of plant growth regulators [PGR] are a crucial factor for the metabolism and accumulation of secondary metabolites and can affect the essential oil content $[1,2]$. Summer savory (Satureja hortensis L.) can be used as a good alternative to conventional synthetic antimicrobial additives in foods [3] and it is widely used in the food, herbal teas, spices, beverage, flavoring material, medicine, drink and perfume industries in the world [4-6]. The essential components of savory are generally phenolic compounds such as carvacrol and thymol, including gamma-terpinene, $\beta$ caryophyllene, p-cymene, linalool and other terpenoids $[4$, 7]. Some investigators have determined that the oil components of the plant are thymol, carvacrol, $\gamma$-terpinene, and borneol [8]. In addition to its application as a natural food preservative and spice, $S$. hortensis, an annual aromatic herb, is known to have been used in the conventional folk medicine in the applications of cardiovascular diseases [9] and muscle pain reliever, intestinal and stomach disorders [10]. Essential oils (EO) and extract of this plant species have antioxidant [11-13], antibacterial-antimicrobial [7, 11, 1315], insecticidal [16, 17], antifungal [11, 18-20] and antigenotoxic activities [21].

Plant growth-promoting rhizobacteria [PGPR] inoculation may be an effective biotechnological tool that stimulates the mechanism of the secondary metabolite production in plants [22]. On the other hand, using different PGR to improve EO yield, composition and content, research that will create an opportunity to change and/or improve the composition of some molecules having economic interest gains importance [23]. Several important bacterial characteristics, such as 
solubilization of inorganic phosphate, biological nitrogen fixation, mineralization of organic matter and solubilization of inorganic phosphate, secretion of certain volatile organic compounds and lowering of plant ethylene level, nutrient uptake, promoting beneficial plant-microbial association, increasing root permeability, production of phytohormones and siderophores, 1-aminocydopropane-1-carboxylic acid deaminase activity, and exhibition of antimicrobial activity against phytopathogenic microorganisms by several mechanisms, can be evaluated as plant growth promotion features and promoted directly or indirectly by many mechanisms such as plant development [23-28]. By efficient use, it is expected that PGPR will make contribution to agronomic efficiency, commonly by reducing environmental pollution and costs, by removing the harmful chemicals.

Agricultural practices can change oil content and composition more or less in medicinal and aromatic plants, PGPR applications are essential for oil synthesis and its role in secondary metabolite production processes are less well known and bacterial IAA and plant growth regulators applications need to be investigated in different medicinal and aromatic plant species. The use of bacterial IAA in medicinal and aromatic plants is an important area of research for increasing the amount of EO and its components. In particular, the possibilities of medicinal and aromatic plants yield, EO content and components to be increased or replaced must be extensively investigated using IAAproducing bacteria. Although some experiments have addressed the role of PGPR inoculation in aromatic plants $[25,29,30]$, the impact of PGPR on physiological features and production of secondary metabolites is poorly known [21]. Therefore, for improve growth and development of these plants whit on native PGPR strains as inoculants have increased significantly day by day research. While our knowledge regarding the potential of PGPR to affect the secondary metabolic pathways of aromatic and medicinal plants remains fragmentary, there are no studies about the effects of theirs on summer savory growth, yield and essential oils. In addition, there is a trend towards biological fertilizer applications and sustainable agricultural systems in the production of medical plants due to environmental impacts which are caused by over application of chemical fertilizers, energies and expenses. That is why, a study was carried out in order to investigate the impact of plant growth regulators and different $\mathrm{N}_{2}$-fixing, IAA-producing, and $\mathrm{P}$ solubilizing bacterial species on growth and development, yield, content and composition of essential oils of summer savory.

\section{Materials and Methods}

\subsection{Bacterial Strains}

Five varied potential PGPR from a pool of 320 rhizobacterial isolates obtained from the oregano (Origanum rotundifolium) and wild raspberry [Rubus ideaus] rhizosphere on the basis of their P-solubilizing, $\mathrm{N}_{2}$-fixing and IAA-producing ability were chosen. Sources and some of biochemical characteristics of the bacterial strains used in the study were given in Table 1 .

Table 1. Isolates used in experiments and some properties.

\begin{tabular}{|c|c|c|c|c|c|c|c|c|}
\hline Bacterial strains $\dagger$ & Source & Gram reaction & Oxidase & Catalase & Sucros & IAA-production & $\mathrm{N}_{2}$-fixation & P-solubilization \\
\hline P. fluorescens RC26 & Raspberry & - & + & + & + & $\mathrm{S}+$ & + & + \\
\hline M. luteus $\mathrm{RC} 17 \mathrm{~A}$ & Raspberry & + & + & + & - & $\mathrm{S}+$ & $\mathrm{S}+$ & + \\
\hline B. subtilis $\mathrm{RC} 17 \mathrm{C}$ & Raspberry & + & $\mathrm{W}+$ & + & + & $\mathrm{S}+$ & $\mathrm{S}+$ & + \\
\hline B. subtilis RC631 & Oregano & + & + & + & + & + & $\mathrm{S}+$ & $\mathrm{W}+$ \\
\hline P. putida $\mathrm{RC} 48$ & Oregano & - & + & + & + & + & + & + \\
\hline
\end{tabular}

$\dagger$ Pseudomonas fluorescens RC26, Micrococcus luteus RC17A, Bacillus subtilis RC17C, Bacillus subtilis RC631, Pseudomonas putida RC48, +: positive; S +: strong positive, $\mathrm{W}+$ : weak positive

\subsection{Greenhouse Experiment, Inoculation and Growth Conditions}

The experiments were carried out a completely randomized design with six replicates (each having four seedlings), having 9 treatments as (1) Control (without bacteria or mineral fertilizers), (2) NPK fertilizer (300 mg N $+300 \mathrm{mg} \mathrm{P}+300 \mathrm{mg} \mathrm{K}$ plant in the compound fertilizer), (3), benzylaminopurine (BAP, $100 \mathrm{ppm}$ ), (4) indole acetic acid + benzylaminopurine (IAA+BAP, 100 ppm), (5) Pseudomonas fluorescens RC26, (6) Pseudomonas putida RC48, (7) Micrococcus luteus RC17A, (8) Bacillus subtilis RC17C and (9) Bacillus subtilis RC63. The experiment was repeated twice. $20 \%$ sodium hypochlorite solution and filled with a loamy soil with an organic matter content of $3.1 \%(\mathrm{w} / \mathrm{w})$, a $\mathrm{pH}$ of 7.4 , total $\mathrm{N}$ of $0.16 \%$, an available Olsen-P content of $17.4 \mathrm{mg} \mathrm{kg}^{-1}$, and available $\mathrm{K}$,
$\mathrm{Ca}$ and $\mathrm{Mg}$ contents of 426, 3260 and $468 \mathrm{mg} \mathrm{kg}^{-1}$, respectively were used to sterilise the pots. Available Fe, $\mathrm{Zn}$, $\mathrm{Mn}$ and $\mathrm{Cu}$ contents were 5.9, 9.3, 1.3, and $1.6 \mathrm{ppm}$, respectively. Chemical fertilizer application is homogeneously mixed during the filling of the sieved soil with the pot.

At the beginning of study, the seed of $S$. hortensis were sown in greenhouse on March, seed pillows of $1 \times 1.5 \mathrm{~m}$ containing sand, peat and virgin soil (1: 1: 1). After two month from sowing, the seedlings with $5-8 \mathrm{~cm}$ height were transplanted to the pots. Pure cultures (50\% strength TSB) were growned in rotary shaker $\left(120 \mathrm{rpm} ; 25^{\circ} \mathrm{C}\right)$ for three days. Bacteria which harvested with centrifugation (ca. 3000 $\mathrm{x} \mathrm{g}$ for $10 \mathrm{~min}$ ) washed and re-suspended in $10 \mathrm{mM}$ sterile phosphate buffer [SPB]. Media $\mathrm{pH}$ is set to 7 for bacteria. . Every one of the PGPR strains is used to vaccinate uniform height young 2-month-old seedlings. Prior to planting for 60 
min, root system of seedlings was plunged into a suspension of every one of PGPR strains for the bacterial inoculation. [31]. Control plants were placed in $5 \mathrm{ml}$ of diluted SPB with no bacteria. Sixty-day-old seedlings of savory were transplanted to the pots. The savory seedlings were grown in a greenhouse under a day-night cycle of 13-11 h natural light $\left(18^{\circ} \mathrm{C}-14^{\circ} \mathrm{C}\right)$ and $60 \%$ relative humidity. Initially, after free drainage had stopped, the pots were measured in order to calculate the mean mass for each soil at field capacity. Pots were watered until reaching up to $100 \%$ of their field capacity and the amount of water diminished every 4 days was applied to the pot. The herbs were manually taken when the weeding is necessary.

\subsection{Plant Material and Isolation of Essential Oil}

The plants were harvested at a height of 5-6 $\mathrm{cm}$ from the ground surface at $50-60 \%$ of the flowering phase and dried in shade. Plant samples which are dried were exposed to plant material which is in boiling water hydro distillation for 3 hours using a Clevenger-type apparatus. Distillation was repeated 3 times for each sample.

\subsection{GC-MS Analysis}

The analysis of the essential oil was performed with gas chromatography-mass spectrometry using the Ultra Thermo desorption unit connected to a quadrupole GC-MS-QP2010 Ultra (EI Quadrapole, Shimadzu, Kyoto, Japan equipped with a HP-5 standart MS fused silica capillary column). This analysis was made according to Adams, R. P. [32].

\subsection{Statistical Analysis}

The experiment was repeated twice. The data were determined according to analysis of variance using SPSS 10.0 software package and when the medium was determined, Duncan's Multiple Range Test was used.

\section{Result}

All vaccinated strains of PGPR were able to produce plant growth-promoting phytohormones, solubilize $\mathrm{P}$, and showed nitrogenase activity (Table 1). Dry herb weight in plants vaccinated with three of the tested bacterial strains was considerably higher than in controls (Table 2). Of the bacterial inoculants, maximum dry herb weight in savory was measured in the $\mathrm{N}_{2}$-fixing, IAA-producing and P-solubilizing Micrococcus luteus RC17A and NPK fertilizer, followed by Pseudomonas fluorescens RC26, Bacillus subtilis RC17C, and exogenous application of indole acetic acid + benzyl amino purine (IAA+BAP) combination, while statistical difference was not seen between the other treatments in terms of dry herb weight.

When compared with the control, average NPK, BAP and IAA+BAP applications increased the essential oil (EO) content, respectively, by $14.6,10.7$ and $24.1 \%$, while inoculations with PGPR by 11.3-32.8\%. In this study, the EO content of summer savory varied from $2.12-2.82 \%$ according to the treatments, while in previous studies on cultivated savory EO was found 1.75-2.3\% [33], 1.30-2.67\% [34], 0,87$1,06 \%$ [4], 2.05\% [35], 0.5-2.9\% [36], 1,66-2,20\% [37], $2,78 \%$ [38] and $1.8-2.0 \%$ [39].

Except for cytokinin [BAP] and P. putida RC48, all treatments increased EO content, and EO and carvacrol yield in dry herb material of Satureja hortensis plants significantly compared to the control; the maximum EO and carvacrol yield in savory were found in RC26 inoculation, followed by RC17A, IAA+BAP, and RC17C. Also, addition of IAA with the BAP increased these characters more than BAP treatment alone. On an average of both trials, seedling inoculation of summer savory with RC26, RC17A, RC17C, RC631, and RC48 increased dry herb yield per plant by 17.4, 23.5, 16.4, 4.2 , and $-3.0 \%$ as compared to the control and EO content by $29.2,18.9,20.8,33.0$, and $11.3 \%$, respectively. NPK and IAA+BAP applications, however, increased dry herb yield up to 18.5 and $13.5 \%$ and essential oil content by 14.6 and $24.1 \%$, respectively. The data suggest that inoculation of summer savory with PGPR increased EO yield per plant by $8.0-51.4 \%$ as compared to the control, and increased carvacrol yield by $3.2-57.2 \%$, depending on the strains. NPK, $\mathrm{BAP}$, and IAA+BAP applications, however, increased EO yield up to $36.7,8.0$, and 40.3 , and carvacrol yield by $32.6,13.4$, and $46.5 \%$, respectively.

According to GC-MS analysis results, S. hortensis was found to contain $98.7-100 \%$ of the total of 31 components depending on the applications of volatile oil. The main components of hydrodistilled oil from aerial parts of $S$. hortensis were carvacrol (48.18-53.96\%), $\gamma$-terpinene (23.76$31.11 \%)$, p-cymene (4.25-7.85\%) and $\alpha$-terpinene (3.91$6.24 \%$ ) followed by $\beta$-myrcene (1.56-2.73\%), $\beta$-bisabolene $(0.67-3.13 \%), \quad \alpha$-thujene $(0.79-2.13 \%), \quad \alpha$-pinene $(0.58$ $2.13 \%), \quad \beta$-pinene $(0.41-2.25 \%), \quad \beta$-caryophyllene $(0.41-$ $1.87 \%), \alpha$-phellandrene $(0.38-0.70 \%)$ and spathulenol $(0.26-$ $0.67 \%$ ) with lower percentages, the amount of all remaining oil constituents was less than $1 \%$, or not found in all samples. According to many studies, carvacrol and $\gamma$-terpinene were considered as the main constituent in oils of $S$. hortensis [4, 33, 35-37, 38, 40-42].

The highest amount of monoterpene hydrocarbons $(\mathrm{MH})$ in EO was obtained with the inoculation of $B$. subtilis RC631 followed by NPK and P. putida RC48, while the highest Oxygenated monoterpenes (MO) ratio was found to be S. hortensis inoculated with P. fluorescens RC26. Control and BAP treatment gave the highest sesquiterpene hydrocarbons (SH) while NPK application gave the lowest $\mathrm{SH}$, bacterial vaccines having values lower than control but higher than NPK were used to apply to the plots (Table 2). The monoterpene prevalence in oil (92.64-98.01\%) was evident, while the most abundant were MO (48.35-54.05\%). In addition, $\mathrm{SH}(1.62$ to 6.21$)$ and $\mathrm{SO}(0.37$ to $0.86 \%)$ were isolated. 
Table 2. Effect of fertilizer, plant growth regulators and rhizobacteria on essential oil content, dry herb, essential oil and carvacrol yield in summer savory.

\begin{tabular}{|c|c|c|c|c|}
\hline Applications $\dagger$ & Dry herb weight $[\mathrm{g} /$ plant $]+$ & Essential oil content $[\%, g / 100$ g dry weight] & Essential oil yield [g/plant] & Carvacol yield [g/plant] \\
\hline Control & $17.02 \pm 0.96 \mathrm{c}$ & $2.12 \pm 0.10 \mathrm{e}$ & $0.362 \pm 0.032 \mathrm{~b}$ & $0.187 \pm 0.002 \mathrm{e}$ \\
\hline NPK & $20.34 \pm 1.61 \mathrm{a}$ & $2.43 \pm 0.09 \mathrm{~cd}$ & $0.495 \pm 0.050 \mathrm{a}$ & $0.248 \pm 0.012 \mathrm{bc}$ \\
\hline $\mathrm{IAA}+\mathrm{BAP}$ & $19.32 \pm 0.93 \mathrm{ab}$ & $2.63 \pm 0.19 \mathrm{a}-\mathrm{c}$ & $0.508 \pm 0.059 \mathrm{a}$ & $0.274 \pm 0.029 \mathrm{a}-\mathrm{c}$ \\
\hline BAP & $16.65 \pm 0.80 \mathrm{c}$ & $2.35 \pm 0.07 \mathrm{de}$ & $0.391 \pm 0.021 \mathrm{~b}$ & $0.212 \pm 0.002 \mathrm{de}$ \\
\hline $\mathrm{RC} 26$ & $19.98 \pm 1.05 \mathrm{a}$ & $2.74 \pm 0.10 \mathrm{ab}$ & $0.548 \pm 0.033 \mathrm{a}$ & $0.294 \pm 0.010 \mathrm{a}$ \\
\hline RC17A & $21.02 \pm 1.35 \mathrm{a}$ & $2.52 \pm 0.21 \mathrm{~b}-\mathrm{d}$ & $0.527 \pm 0.024 \mathrm{a}$ & $0.281 \pm 0.013 \mathrm{ab}$ \\
\hline $\mathrm{RC} 17 \mathrm{C}$ & $19.81 \pm 1.85 \mathrm{a}$ & $2.56 \pm 0.19 \mathrm{~b}-\mathrm{d}$ & $0.507 \pm 0.044 \mathrm{a}$ & $0.264 \pm 0.016 \mathrm{a}-\mathrm{c}$ \\
\hline RC631 & $17.73 \pm 0.81 \mathrm{bc}$ & $2.82 \pm 0.18 \mathrm{a}$ & $0.500 \pm 0.040 \mathrm{a}$ & $0.241 \pm 0.027 \mathrm{~cd}$ \\
\hline $\mathrm{RC} 48$ & $16.51 \pm 1.65 \mathrm{c}$ & $2.36 \pm 0.14 \mathrm{de}$ & $0.391 \pm 0.058 \mathrm{~b}$ & $0.193 \pm 0.030 \mathrm{e}$ \\
\hline Average & $18.60 \pm 2.00$ & $2.50 \pm 0.25$ & $0.470 \pm 0.076$ & $0.243 \pm 0.403$ \\
\hline
\end{tabular}

$\dagger$ Control: without bacteria inoculation or mineral fertilizers; Bacterial strains are explained in Table 1;

tValues followed by different letters in a column were significantly different $[p<0.05]$, using Duncan's multiple range test; Data were means \pm standard error of six replicates.

The biosynthesis of the major EO constituents was enhanced in the vaccinated plants. The maximum carvacrol and spathulenol in EO were obtained with treatment of IAA+BAP, BAP and inoculation RC26, and $\gamma$-terpinene and p-cymene in EO were obtained with NPK fertilization and RC48 inoculation, respectively. IAA + BAP resulted in an increase in the yield of EO and carvacrol without much influence on the main compounds, but with some change in the composition such as the increase and appearance of $[\alpha-$ thujene, $\beta$-myrcene, carvacrol, limonene, and spathulenol] and reduce of [p-cymene, $\beta$-caryophyllene and $\beta$-bisabolene]. All five PGPR strains evaluated produced a significant increase in $\alpha$-thujene, $\beta$-myrcene and $\alpha$-terpinene content, but only RC17A, RC17C and RC631 strains and NPK treatment enhanced $\gamma$-terpinene, and only RC48 increased p-cymene content. In this study, $\alpha$-thujene, $\alpha$ - pinene, $\alpha$-terpinene, $\beta$ pinene, $\mathrm{p}$-cymene and $\gamma$-terpinene were the most influenced monoterpenes. While the highest $\beta$-caryophyllene and $\beta$ bisabolene rate in oil was determined in control application, other components were changed with bacteria inoculations. Moreover, the use of plant growth regulators (IAA+BAP) and inoculation with $\mathrm{RC} 17 \mathrm{C}$ and $\mathrm{RC} 48$ caused the appearance of limonene and disappearance of sylvestrene.

Table 3. Effect of mineral fertilizer, rhizobacteria and plant growth regulators on essential oil components of summer savory.

\begin{tabular}{|c|c|c|c|c|c|c|c|c|c|}
\hline \multirow{2}{*}{ Compounds } & \multicolumn{9}{|c|}{ Treatments: } \\
\hline & Control & NPK & $\mathbf{I A A}+\mathbf{B A P}$ & BAP & RC26 & RC17A & RC17C & RC631 & RC48 \\
\hline$\alpha$-thujene & $0.87 \mathrm{~d}$ & $1.46 \mathrm{~b}$ & $1.10 \mathrm{c}$ & $0.79 \mathrm{~d}$ & $1.25 \mathrm{c}$ & $1.14 \mathrm{c}$ & $1.25 \mathrm{c}$ & $2.09 \mathrm{a}$ & $2.13 \mathrm{a}$ \\
\hline$\alpha$-pinene & $0.65 \mathrm{de}$ & $0.76 \mathrm{~d}$ & $0.58 \mathrm{e}$ & $0.64 \mathrm{de}$ & $1.06 \mathrm{c}$ & $0.70 \mathrm{de}$ & $0.78 \mathrm{~d}$ & $1.31 \mathrm{~b}$ & $2.13 \mathrm{a}$ \\
\hline Camphene & & & & & & & & & 0.20 \\
\hline Sabinene & & 0.12 & & & 0.15 & & & & \\
\hline$\beta$-pinene & $0.47 \mathrm{~d}$ & $0.46 \mathrm{~d}$ & $0.47 \mathrm{~d}$ & $0.53 \mathrm{~cd}$ & $0.46 \mathrm{~d}$ & $0.41 \mathrm{~d}$ & $0.60 \mathrm{c}$ & $0.91 \mathrm{~b}$ & $2.25 \mathrm{a}$ \\
\hline$\beta$-myrcene & $1.64 \mathrm{c}$ & $2.21 \mathrm{~b}$ & $2.03 \mathrm{~b}$ & $1.56 \mathrm{c}$ & $2.73 \mathrm{a}$ & $2.04 \mathrm{~b}$ & $2.05 \mathrm{~b}$ & $2.73 \mathrm{a}$ & $2.26 \mathrm{~b}$ \\
\hline$\delta$-3-carene & & 0.10 & & & & & & & 0.12 \\
\hline$\alpha$-terpinene & $4.25 \mathrm{e}$ & $5.23 \mathrm{bc}$ & $4.75 \mathrm{~cd}$ & $3.91 \mathrm{e}$ & $5.31 \mathrm{~b}$ & $4.57 \mathrm{~d}$ & $4.79 \mathrm{~b}-\mathrm{d}$ & $6.24 \mathrm{a}$ & $4.52 \mathrm{~d}$ \\
\hline p-cymene & $5.56 \mathrm{~b}$ & $4.99 \mathrm{c}$ & $4.81 \mathrm{c}$ & $4.30 \mathrm{~d}$ & $4.37 \mathrm{~d}$ & $4.25 \mathrm{~d}$ & $5.12 \mathrm{c}$ & $5.64 \mathrm{~b}$ & $7.85 \mathrm{a}$ \\
\hline Sylvestrene & 0.34 & 0.82 & & 0.60 & & 0.79 & & 1.00 & \\
\hline Limonene & & & 0.77 & & & & 0.79 & & 1.02 \\
\hline$\beta$-phellandrene & & & & & 0.45 & & & & \\
\hline$[Z]$ - $\beta$-ocimene & & & & & & & & & 0.37 \\
\hline $\begin{array}{l}\text { Trans-sabinene hydrate } \\
\alpha \text {-terpinolene }\end{array}$ & 0.04 & 0.11 & & 0.18 & & & 0.20 & 0.17 & 0.20 \\
\hline Borneol & 0.17 & & & & & & & & 0.17 \\
\hline$\alpha$-terpineol & & & & & & & & & 0.14 \\
\hline Carvacrol methyl ether & 0.65 & 0.09 & & & 0.16 & 0.12 & & 0.17 & 0.65 \\
\hline Carvacrol & $51.89 \mathrm{ab}$ & $50.02 \mathrm{bc}$ & $53.92 \mathrm{a}$ & $53.96 \mathrm{a}$ & $53.89 \mathrm{a}$ & $53.05 \mathrm{ab}$ & $51.91 \mathrm{ab}$ & $48.18 \mathrm{c}$ & $49.72 \mathrm{bc}$ \\
\hline Carvacrol acetate & 0.05 & & & & & 0.22 & 0.28 & & \\
\hline$\beta$-caryophyllene & $1.87 \mathrm{a}$ & $0.59 \mathrm{~d}$ & $0.95 \mathrm{bc}$ & $1.80 \mathrm{a}$ & $0.96 \mathrm{bc}$ & $1.10 \mathrm{~b}$ & $0.97 \mathrm{~b}$ & $0.80 \mathrm{c}$ & $0.41 \mathrm{e}$ \\
\hline Aromadendrene & 0.35 & & 0.30 & 0.53 & & & & & \\
\hline$\gamma$-selinene & & & & & & & & & 0.07 \\
\hline Bicyclogermacrene & 0.77 & & & 0.49 & 0.53 & & & 0.22 & 0.48 \\
\hline Cis- $\alpha$-bisabolene & 0.09 & & & 0.21 & & 0.14 & & & \\
\hline Spathulenol & $0.52 \mathrm{~b}$ & $0.26 \mathrm{~d}$ & $0.67 \mathrm{a}$ & $0.57 \mathrm{~b}$ & $0.53 \mathrm{~b}$ & $0.50 \mathrm{~b}$ & $0.52 \mathrm{~b}$ & $0.40 \mathrm{c}$ & $0.37 \mathrm{c}$ \\
\hline Caryophyllene oxide & 0.10 & 0.10 & & 0.30 & & 0.20 & 0.15 & & \\
\hline 3-fluorophenyl & 0.04 & 0.22 & & & & 0.16 & 0.14 & & \\
\hline
\end{tabular}




\begin{tabular}{|c|c|c|c|c|c|c|c|c|c|}
\hline \multirow{2}{*}{ Compounds } & \multicolumn{9}{|c|}{ Treatments: } \\
\hline & Control & NPK & IAA+BAP & BAP & RC26 & RC17A & RC17C & RC631 & RC48 \\
\hline $\mathrm{MO}$ & $52.77 \mathrm{ab}$ & $50.11 \mathrm{ab}$ & $53.92 \mathrm{a}$ & $53.96 \mathrm{a}$ & $54.05 \mathrm{a}$ & $53.39 \mathrm{a}$ & $52.19 \mathrm{ab}$ & $48.35 \mathrm{~b}$ & $50.68 \mathrm{ab}$ \\
\hline SH & $6.21 \mathrm{a}$ & $1.32 \mathrm{f}$ & $2.87 \mathrm{c}$ & $4.97 \mathrm{~b}$ & $2.92 \mathrm{c}$ & $2.65 \mathrm{c}$ & $2.17 \mathrm{~d}$ & $1.85 \mathrm{de}$ & $1.63 \mathrm{ef}$ \\
\hline SO & $0.67 \mathrm{~b}$ & $0.58 \mathrm{c}$ & $0.67 \mathrm{~b}$ & $0.87 \mathrm{a}$ & $0.53 \mathrm{c}$ & $0.86 \mathrm{a}$ & $0.81 \mathrm{a}$ & $0.40 \mathrm{~d}$ & $0.37 \mathrm{~d}$ \\
\hline Total identified & 99.52 & 99.91 & 100 & 98.66 & 99.98 & 99.95 & 99.84 & 100 & 100 \\
\hline
\end{tabular}

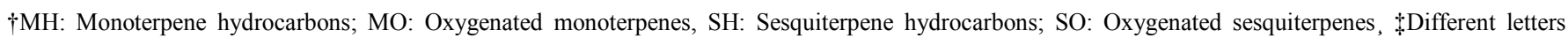
within the same line indicate significant differences according to Duncan's Multiple Range Test $[p \leq 0.05]$.

\section{Discussion}

It is clear that the influence of PGR and PGPR on the both EO content and its composition are the most important quality criteria for summer savory in all purposes. The production of auxin (IAA), has been accepted as a significant element in direct plant-growth-promoting abilities of rhizosphere bacteria [43]. Also exogenous application of PGR could affect EO production and chemical compositions. Plant growth regulators have been determined as one of the main elements influence plants growth and their primary and secondary metabolites pool, and could affect EO production and chemical composition. The BAP and IAA caused an increase in the yield of EO of $O$. gratissimum without much influence on the main compounds [23], but with some change in the composition. Application of auxin and cytokinin increased some components, medicinal and nutritional values of the lemon balm and verbena [44, 45], enhanced callus induction and shoot and root formation in in vitro culture of lemon balm [46] and volatile compounds such as thymol of thyme [47]. On the other hand, in the previous survey, it can be seen that the spraying with BAP on plants leads to an increase of the plant weight, leaf density and area of the glandular hairs [22].

In this study we are trying to examine the effects of different PGPR on yield, content and composition of EO in order to have opportunity to develop and/or change the composition of some molecules having economical interest. Moreover, qualitative and quantitative changes in the major monoterpene components and sesquiterpene content of plant oil were observed in response to the effect of varying growth regulators and bacterial strains, by the host plant in a strain-specific attitude. Exogenous application of cytokinin (BAP) and auxin (IAA) have the effect of increasing the yield of EO without considerable qualitative change.

Bacterial inoculation affected the chemical composition of EO and increased the production of monoterpenes. The inoculated plants, in comparison with controls, showed increases yield, composition and content of EO, and marked qualitative and quantitative changes in some molecules having economical interest. Recent studies have shown that bacterial inoculation affected density, size, number, formation and interfered with the chemistry of glandular trichomes which probably enhanced the EO synthesis [48, 49]. PGPR inoculations, a potential alternative in plant production, had an increased oil content and yield in calendula [50], induced biosynthesis of secondary metabolites, and affected pathway flux or specific steps of monoterpene metabolism [25], and improved the production of monoterpenes and main constituents [21, 25, 29, 45, 51, 52]. It has been found that PGPR significantly enhances in root and shoot biomass, node number, leaf area, glandular trichome number and density, and stomatal density, EO yield and biosynthesis of major EO components, and marked qualitative and quantitative changes in monoterpene content of peppermint [21, 52], produce high density and large of glandular trichomes, it could be suitable for secondary metabolite production of yellow lapacho [53], increase total EO yield and phenolic content in oregano and thyme $[30,51]$, and increase root and shoot dry weight, $\mathrm{P}, \mathrm{N}$ and $\mathrm{K}$ content, and EO of sweet basil [54]. The positive impacts of these strains on growth, yield, oil content and compositions of summer savory plants indicates the useful role of these PGPR, which might be attributed to IAA production, P-solubilisation, $\mathrm{N}_{2}$-fixation or even other non-evaluated PGPR traits that stimulate plant.

\section{Conclusion}

Improved knowledge of the factors that control or affect monoterpene accumulation and biosynthesis of secondary metabolites will cause strategies for advanced productivity and cultivation of aromatic plants without the use of chemical fertilizers or PGR. PGPR have clear potential for improving the productivity of aromatic plants, and may significantly enhance plant growth and diminish the amount of fertilizers needed for economically sustainable crop production. Bacterial inoculants may be an efficient biotechnological tool for stimulating secondary metabolism in medicinal and aromatic plants, and studies of their activities will enhance our understanding of processes that affect the accumulation of phenolic compounds and monoterpenes for a variety of treatments in food and cosmetic industries, and poorly understand at present. Microbial strategy presents an attractive way to replace the use of chemical fertilizers for aromatic and medicinal plants, but little is known about their potential effect and ability of PGPR to increase plant secondary metabolites. Multi-traits PGPR inoculation can significantly modify both the content and composition of EO in savory, and seem to be an important factor modifying their aromatic profile. Also, more studies are necessary to examine the probable mechanisms by which bacteria enhance phytochemical constituents in medicinal plants at the tissue, cell, or molecular level.

\section{Acknowledgements}

This article is prepared to based on the master thesis of Goltay MOSBER. 


\section{References}

[1] Karalija, E., Parić, A. 2011. The effect of BA and IBA on the secondary metabolite production by shoot culture of Thymus vulgaris L. Biologica. Nyssana. 2(1): 29-35.

[2] Sharafzadeh, S., Zare, M. 2011. Influence of growth regulators on growth and secondary metabolites of some medicinal plants from lamiaceae family. Adv. Environ. Biol 5: 22962302 .

[3] Bezić, N., Šamanić, I., Dunkić, V., Besendorfer, V., Puizina, J. 2009. Essential oil composition and internal transcribed spacer (ITS) sequence variability of four South-Croatian Satureja species (Lamiaceae). Molecules. 14: 925-938.

[4] Sefidkon. F., Abbasi, K., Khaniki, G. B. 2006. Influence of drying and extraction methods on yield and chemical composition of the essential oil of Satureja hortensis. Food Chem. 99: 19-23.

[5] Skocibusic, M., Bezic, N., Dunkic, V. 2006. Phytochemical composition and antimicrobial activities of the essential oils from Satureja subspicata Vis. growing in Croatia. Food Chem. 96:20-28.

[6] Teshome, I., Teshome, S., Soromessa, T., Feyissa, T. 2016. Development of an efficient in vitro propagation protocol for Satureja punctata - A rare aromatic and medicinal plant. Taiwania. 61: 41-48.

[7] Şahin, F., Karaman, I., Güllüce, M., Oğütçü, H., Şengül, M., Adigüzel, A., Ozturk, S., Kotan, R. 2003 Evaluation of antimicrobial activities of Satureja hortensis L. J. Ethnopharmacol. 87:61-65.

[8] Boskabady, M. H., Aslani, M. R., Mansuri, F., Amery, S. 2007. Relaxant effect of Satureja hortensis on guinea pig tracheal chains and its possible mechanism (s). Daru. 5(4): 199-204.

[9] Yazdanparast, R., Shahriyary, L. 2008 Comparative effects of Artemisia dracunculus, Satureja hortensis and Origanum majorana on inhibition of blood platelet adhesion, aggregation and secretion. Vascular Pharmacol. 48: 32-37.

[10] Hajhashemi. V., Sadraei, H., Ghannadi, A. R., Mohseni, M. 2000. Antispasmodic and anti-diarrhoeal effect of Satureja hortensis L. essential oil. J. Ethnopharmacol. 71:187-92.

[11] Güllüce, M., Sökmen, M., Daferera, D., Ağar, G., Ozkan, H., Kartal, N., Polissiou, M., Sökmen, A., Sahin, F. 2003. In vitro antibacterial, antifungal, and antioxidant activities of the essential oil and methanol extracts of herbal parts and callus cultures of Satureja hortensis L. J. Agric. Food. Chem. 51:3958-3965.

[12] Dorman, H. J. D., Hiltunen, R. 2004. Fe (III) reductive and free radical-scavenging properties of summer savory (Satureja hortensis L.) extract and subfractions. Food Chem. 88: 193199.

[13] Shojaee-Aliabadi, S., Hosseini, H., Mohammadifar, M. A., Mohammadi, A., Ghasemlou, M., Ojagh, S., Hosseini, S. M., Khaksar, R. 2013. Characterization of antioxidantantimicrobial k-carrageenan films containing Satureja hortensis essential oil. Int. J. Biol. Macromol. 52:116-124.

[14] Adiguzel, A., Ozer, H., Kilic, H., Cetin, B. 2007. Screening of antimicrobial activity of essential oil and methanol extract of
Satureja hortensis on foodborne bacteria and fungi. Czech. J. Food. Sci. 25: 81-89.

[15] Kotan, R., Dadasoglu, F., Karagoz, K., Cakir, A., Ozer, H., Kordali, S., Cakmakci, R., Dikbas, N. 2013. Antibacterial activity of the essential oil and extracts of Satureja hortensis against plant pathogenic bacteria and their potential use as seed disinfectants. Sci. Hort. 153: 34-41.

[16] Pavela, R., Sajfrtova, M., Sovova, H., Barnet, M. 2008. The insecticidal activity of Satureja hortensis L. extracts obtained by supercritical fluid extraction and traditional extraction techniques. Appl. Entomol. Zool. 43:377-382.

[17] Tozlu, E., Cakir, A., Kordali, S., Tozlu, G., Ozer, H., Akcin, T. A. 2011. Chemical compositions and insecticidal effects of essential oils isolated from Achillea gypsicola, Satureja hortensis, Origanum acutidens and Hypericum scabrum against broadbean weevil (Bruchus dentipes). Sci. HortıcAmsterdam. 130:9-17.

[18] Boyraz, N., Ozcan, M. 2006. Inhibition of phytopathogenic fungi by essential oil, hydrosol, ground material and extract of summer savory (Satureja hortensis L.) growing wild in Turkey. Int. J. Food Microbiol. 107: 238-242.

[19] Razzaghi-Abyaneh, M., Shams-Ghahfarokhi, M., Yoshinari, T., Rezaee, M. B., Jaimand, K., Nagasawa, H., Sakuda, S. 2008. Inhibitory effects of Satureja hortensis L. essential oil on growth and aflatoxin production by Aspergillus parasiticus. Int. J. Food Microbiol. 123: 228-233.

[20] Gumus, T, 2010. Determination of the changes of antifungal properties of Satureja hortensis, Thymus vulgaris and Thymbra spicata exposed to gamma irradiation. Radiat. Phys. Chem. 79:109-114.

[21] Cappellari, L. R., Santoro, M. V., Reinoso, H., Travaglia, C., Giordano, W., Banchio, E. 2015. Anatomical, morphological, and phytochemical effects of inoculation with plant growthpromoting rhizobacteria on peppermint (Mentha piperita). J. Chem. Ecol. 41:149-158.

[22] Mosaffa, F., Behravan, J., Karimi, G., Iranshahi, M. 2006. Antigenotoxic effects of Satureja hortensis 1. on rat lymphocytes exposed to oxidative stress. Arch. Pharm. Res. 29:159-164.

[23] Hazzoumi, Z., Moustakime, Y., Joutei, K. A. 2014. Effect of gibberellic acid (GA), indole acetic acid (IAA) and benzylaminopurine (BAP) on the synthesis of essential oils and the isomerization of methyl chavicol and trans-anethole in Ocimum gratissimum L. SpringerPlus. 3(321): 1-7.

[24] Şahin, F., Çakmakçı, R., Kantar, F. 2004. Sugar beet and barley yields in relation to inoculation with $\mathrm{N}_{2}$-fixing and phosphate solubilizing bacteria. Plant Soil. 265:123-129.

[25] Santoro, M. V., Zygadlo, J., Giordano, W., Banchio, E. 2011. Volatile organic compounds from rhizobacteria increase biosynthesis of essential oils and growth parameters in peppermint (Mentha piperita). Plant Physiol. Bioch. 49:11771182.

[26] Bhattacharyya, P. N., Jha, D. K. 2012. Plant growth-promoting rhizobacteria (PGPR): emergence in agriculture. World J. Microbiol. Biotechnol. 28: 1327-1350.

[27] Chauhan, H., Bagyaraj, D. J., Selvakumar, G., Sundaram, S. P. 2015. Novel plant growth promoting rhizobacteria-prospects and potential. Appl. Soil Ecol. 95:38-53. 
[28] Çakmakçı, R., Turan, M., Güneş, N. A., Nikerel, E., Özdemir, B. S., Yıldırım, E., Olgun, M., Topçuoğlu, B., Tüfenkçi, Ş., Karaman, M. R., Tarhan, L., Mokhtari, N. E. P. 2017. The role of soil beneficial bacteria in wheat production: A Review. In Wheat Improvement, Management and Utilization, eds. R. Wanyera and J. Owuoche, 115-149. In Tech. Rijeka, Croatia.

[29] Banchio, E,. Xie, X., Zhang, H., Paré, P. W. 2009. Soil bacteria elevate essential oil accumulation and emissions in sweet basil. J. Agric. Food. Chem. 57: 653-657.

[30] Cappellari, L. R., Santoro, M. V., Nievas, F., Giordano, W., Banchio, E. 2013. Increase of secondary metabolite content in marigold by inoculation promoting rhizobacteria. Appl. Soil Ecol. 70: 16-22.

[31] Çakmakçı, R. 2016. Screening of multi-trait rhizobacteria for improving the growth, enzyme activities, and nutrient uptake of tea (Camellia sinensis). Commun. Soil. Sci. Plan. 47:16801690 .

[32] Adams, R. P. 2007. Identification of essential oil components by gas chromatography/mass spectrometry. 4th edition. Allured Publishing Corp, Carol Stream, IL. USA.

[33] Baher, Z. F., Mirza, M., Ghorbanli, M., Rezaii, M. B. 2002. The influence of water stress on plant height, herbal and essential oil yield and composition in Satureja hortansis L. Flavour Fragr. J. 17: 275-277.

[34] Başer, K. H. C., Özek, T., Kirimer, N., Tümen, G. 2004. A comparative study of the essential oils of wild and cultivated Satureja hortensis L. J. Essent. O1l. Res. 16: 422-424.

[35] Mihajilov-Krstev, T., Radnović, D., Kitić, D., Zlatković, B., Ristić, M., Branković, S. 2009. Chemical composition and antimicrobial activity of Satureja hortensis L. essential oil. Cent. Eur. J. Biol. 4: 411-416.

[36] Hadian, J., Ebrahimi, S. N., Salehi, P. 2010. Variability of morphological and phytochemical characteristics among Satureja hortensis L. accessions of Iran. Ind. Crop. Prod. 32: 62-69.

[37] Katar. D, Arslan, Y., Subaşı, I., Bülbül, A. 2011. Determination of ontogenetic variability of essential oil content and components in summer savory (Satureja hortensis L) in Ankara ecological conditions JOTAF 8: 29-36

[38] Kargar, V., Alizadeh, A., Namayandeh, A. 2014. Essential oil constituents of Satureja sahendica Bornm. and Satureja hortensis L. cultivated in Iran . Intl. J. Farm. Alli. Sci. 3 (1): 91-94.

[39] Farahani, E., Roudgarmi, P., Naderi, G. 2015. The effect of different fertilizers on grow parameter, yield and essential oil quantity of summer savory in Iran. DAVIJS 4 (2): 611-621.

[40] Najafi, F., Khavari-Nejad, R. A., Siah-Ali, M. 2010. The effects of salt stress on certain physiological parameters in summer savory (Satureja hortensis L.) plant. Journal of Stress Physiology and Biochemistry. 6: 13-21.

[41] El-Gohary, A. E., El Gendy, A. G., Hendawy, S. F., ElSherbeny, S. E., Hussein, M. S., Geneva, M. 2015. Herbage yield, essential oil content and composition of summer savory (Satureja hortensis L.) as affected by sowing date and foliar nutrition. Genet. Plant Physiol. 5(2): 170-178.

[42] Radácsi, P., Inotai, K., Sárosi, S., Németh, E. 2016. Effect of soil water content on the physiological parameters, production and active substances of summer savory (Satureja hortensis L.). Acta. Sci. Pol-Hortoru. 15: 3-12.

[43] Egamberdieva, D., Kucharova, Z., Davranov, K., Berg, G., Makarova, N., Azarova, T., ... \& Lugtenberg, B. (2011). Bacteria able to control foot and root rot and to promote growth of cucumber in salinated soils. Biology and fertility of soils, 47(2), 197-205.

[44] Silva, S., Sato, A., Lage, C. L. S., Gil, Azevedo DA. S., Esquibel, M. A. 2005. Essential oil composition of Mellisa officinalis L. in vitro produced under the influence of growth regulators. J. Brazil. Chem. Soc. 16:1387-1390.

[45] Nourafcan, H., Sefidkon, F., Khalighi, A., Mousavi, A., Sharifi, M. 2014 Effects of IAA and BAP on chemical composition and essential oil content of lemon verbena (Lippia citriodora H. B. K.). Journal of Herbal Drugs. 5: 2532.

[46] Mohebalipour, N., Aharizad, S., Mohammadi, S. A., Motallebiazar, A. R., Maddah Arefi, H. 2012. Effect of plant growth regulators BAP and IAA on micropropagation of Iranian lemon balm (Melissa officinalis L.) landraces. J. Food Agric. Environ. 10: 280-286.

[47] Affonso, V. R., Bizzo, H. R., Lage, C. L. S., Sato, A. 2009. Influence of growth regulators in biomass production and volatile profile of in vitro plantlets of Thymus vulgaris L. J. Agric. Food. Chem. 57: 6392-6395.

[48] Dharni, S., Srivastava, A. K., Samad, A., Patra, D. D. 2014. Impact of plant growth promoting Pseudomonas monteilii PsF84 and Pseudomonas plecoglossicida PsF610 on metal uptake and production of secondary metabolite (monoterpenes) by rose-scented geranium (Pelargonium graveolens cv. bourbon) grown on tannery sludge amended soil. Chemosphere. 117: 433-439.

[49] Lommen, W. J. M., Schenk, E., Bouwmeester, H. J., Verstappen, F. W. A. 2006. Trichome dynamics and artemisinin accumulation during development and senescence of Artemisia annua leaves. Planta. Med. 72:336-345.

[50] Kammak, F. D., Dahmardeh, M., Khammari, I., Rahimian, A. R. 2015. The effect of application type and composition of growth stimulating bacteria on quantitative and qualitative characteristics of medicinal plant calendula (Calendula officinallis L.). Indian J. Sci. Technol. 8(13): 1-9.

[51] Banchio, E., Bogino, P. C., Santoro, M., Torres, L., Zygadlo, J., Giordano, W. 2010. Systemic induction of monoterpene biosynthesis in Origanum majoricum by soil bacteria. J. Agric. Food. Chem. 58: 650-654.

[52] Santoro, M. V., Cappellari, L. R., Giordano, W., Banchio, E. 2015. Plant growth-promoting effects of native Pseudomonas strains on Mentha piperita (peppermint): an in vitro study. Plant. Biol. 17:1218-1226.

[53] Llorente, B. E., Alasia, M. A., Larraburu, E. E. 2016. Biofertilization with Azospirillum brasilense improves in vitro culture of Handroanthus ochraceus, a forestry, ornamental and medicinal plant. New Biotechnol. 33:32-40.

[54] Ordookhani, K., Sharafzadeh, S., Zare, M. 2011. Influence of PGPR on growth, essential oil and nutrients uptake of sweet basil. Adv. Environ. Biol 5(4): 672-677. 